\title{
Gambaran Pengelolaan Limbah Medis Padat pada Pos Kesehatan Desa (Poskesdes) di Kecamatan Bluto
}

\section{Description Management of Solid Medical Waste at Village Health Posts in Bluto District}

\author{
Laylatul Hasanah ${ }^{1)}$ dan Nelyta Oktavianisya ${ }^{2)}$ \\ ${ }^{1}$ Program Studi Kebidanan, Fakultas Ilmu Kesehatan, Universitas Wiraraja \\ email : laylatulhasanah@wiraraja.ac.id \\ ${ }^{2}$ Program Studi Ners, Fakultas Ilmu Kesehatan, Universitas Wiraraja
}

\begin{abstract}
Village health posts are one of the public health services in villages that provide many health services such as examination of pregnant women, treatment of patients, first aid in the event of an accident, examination in the elderly, and other health services. Exposure to health care waste can result in illness or injury to health workers, patients, visitors and the community around the health facility environment even though the proportion of medical waste that falls into the category of hazardous waste is only $15-25 \%$, but the risk is quite large. WHO predicts the risk of sharps waste by 1\% of total health waste in 2000. This is a risk because it able to spread infection of hepatitis $B$ and hepatitis $C$. Based on data solid medical waste generated from village healt post service activities ranges between $0.5 \mathrm{~kg}$ per month up to $2 \mathrm{~kg}$ per month per village healt post, the management is not done directly by the Bluto puskesmas because there is no incinerator. The research was used descriptive. Object of study including environmental health officers and 2 staff of environmental health officers at Bluto Health Center. The research instrument used an interview sheet, and the observation sheet described the management of solid medical waste at 17 poskesdes in Bluto District. The management of solid medical waste at 17 poskesdes in Bluto sub-district from 4 aspects ranging from shelter and sorting, collection, transportation and destruction and final disposal as a whole has been good this was related to coordination between poskesdes officers and puskesmas officers to conduct good medical solid waste management by carrying out an MoU with a third party as the party who will carry out the final activities on solid medical waste.
\end{abstract}

Keywords; solid medical waste, management, village health post

\begin{abstract}
Abstrak
Pos kesehatan desa (Poskesdes) merupakan salah satu tempat pelayanan kesehatan masyarakat yang berada di desa yang menyediakan banyak layanan kesehatan misalnya pemeriksaan ibu hamil, perawatan pada pasien, pertolongan pertama jika terjadi kecelakaan, pemeriksaan pada lanjut usia, dan pelayanan kesehatan lainnya. Pajanan limbah layanan kesehatan dapat mengakibatkan penyakit atau cidera petugas kesehatan, pasien, pengunjung dan masyarakat disekitar lingkungan fasilitas kesehatan meskipun proporsi limbah medis yang masuk ke dalam kategori limbah berbahaya hanya sebesar 15 - 25\%, tetapi risiko yang ditimbulkan cukup besar. Word Health Organization (WHO) memprediksi risiko limbah benda tajam sebesar $1 \%$ dari total limbah kesehatan pada tahun 2000. Hal ini menjadi resiko karena mampu menyebarkan infeksi
\end{abstract}


hepatitis B dan hepatitis C. Berdasarkan data Limbah medis padat yang dihasilkan dari kegiatan pelayanan poskesdes berkisar antara 0,5 kg perbulan sampai dengan $2 \mathrm{~kg}$ perbulan setiap poskesdes, pengelolaan tidak dilakukan langsung oleh puskesmas Bluto karena tidak ada incenerator. Penelitan ini menggunakan metode deskriptif. Obyek penelitian diantaranya petugas kesehatan lingkungan dan 2 staff petugas kesehatan lingkungan di Puskesmas Bluto. Instrumen penelitian menggunakan lembar wawancara, dan lembar observasi menggambarkan pengelolaan limbah medis padat pada 17 poskesdes di Kecamatan Bluto. Pengelolaan limbah medis padat pada 17 poskesdes di Kecamatan Bluto dari 4 aspek mulai dari penampungan dan pemilahan, pengumpulan, pengangkutan serta pemusnahan dan pembuangan akhir secara keseluruhann sudah baik hal ini berkaitan dengan koordinasi antara petugas poskesdes dan petugas puskesmas untuk melakukan pengelolaan limbah padat medis yang baik dengan melakukan MoU dengan pihak ketiga sebagai pihak yang akan melakukan kegiatan akhir pada limbah medis padat.

Kata kunci; limbah medis padat, pengelolaan, pos kesehatan desa

\section{PENDAHULUAN}

Masalah lingkungan erat sekali hubungannya dengan dunia kesehatan untuk mencapai kondisi masyarakat yang sehat diperlukan lingkungan yang baik pula, pos kesehatan desa merupakan salah satu tempat pelayanan kesehatan masyarakat yang berada di desa yang menyediakan banyak layanan kesehatan misalnya pemeriksaan ibu hamil, perawatan pada pasien, pertolongan pertama jika terjadi kecelakaan, pemeriksaan pada lanjut usia, dan pelayanan kesehatan lainnya. Kegiatan pelayanan kesehatan yang di lakukan di pos kesehatan desa banyak menimbulkan sampah atau limbah, yang terdiri dari limbah medis padat dan limbah cair serta limbah non medis yang timbul karena kegiatan pelayanan kesehatan. Limbah medis padat merupakan hasil dalam rangkaian kegiatan layanan kesehatan berpotensi tinggi menimbulkan infeksi dan cedera (WHO, 2005).

Pajanan limbah layanan kesehatan dapat mengakibatkan penyakit atau cidera petugas kesehatan, pasien, pengunjung dan masyarakat disekitar lingkungan fasilitas kesehatan meskipun proporsi limbah medis yang masuk ke dalam kategori limbah berbahaya hanya sebesar $15-25 \%$, tetapi risiko yang ditimbulkan cukup besar. WHO memprediksi risiko limbah benda tajam sebesar $1 \%$ dari total limbah kesehatan pada tahun 2000. Hal ini menjadi resiko karena mampu menyebarkan infeksi hepatitis B dan hepatitis C (Agustina, 2014).

Limbah medis merupakan porsi yang lebih besar dari infeksi limbah, yang berpotensi berbahaya karena mereka mungkin berisi agen patogen. Produksi limbah ini akan terus menjadi fenomena yang terus berlangsung sepanjang ada kegiatan manusia. Pengelolaan limbah medis adalah isu baru yang diperbesar oleh kurangnya pelatihan, kesadaran, dan sumber daya keuangan untuk mendukung solusi. Pengumpulan dan pembuangan limbah sangat penting karena memiliki dampak langsung terhadap risiko kesehatan masyarakat dan kesehatan lingkungan (Bilpinar et al., 2009).

Pengelolaan limbah harus dilakukan dengan benar dan efektif serta memenuhi persyaratan sanitasi. Sebagai suatu yang tidak digunakan lagi, tidak disenangi, dan harus dibuang maka limbah tentu harus dikelola dengan baik. Pengelolaan sampah merupakan kegiatan yang sistematis, menyeluruh dan berkesinambungan yang meliputi pengurangan, penanganan dan pemusnahan limbah (Agustina, 2014).

Pengelolaan limbah medis padat bahan berbahaya dan beracun (B3) adalah penanganan limbah padat B3 (medis) yang dimulai sejak dari pewadahan dan pengumpulan hingga pengolahan dan penimbunan atau pemusnahan. Limbah 
medis merupakan masalah yang cukup serius, sehingga banyak upaya yang dilakukan oleh pemerintah daerah, swasta maupun secara swadaya oleh masyarakat untuk menanggulanginya, dengan cara mengurangi, mendaur ulang maupun memusnahkannya. Limbah yang dihasilkan dari upaya medis seperti Puskesmas, Poliklinik dan Rumah Sakit yaitu jenis limbah yang termasuk dalam kategori biohazard yaitu jenis limbah yang sangat membahayakan lingkungan, dimana banyak terdapat buangan virus, bakteri maupun zat - zat yang membahayakan lainnya, sehingga harus dimusnahkan dengan jalan dibakar dalam suhu di atas $1000^{\circ} \mathrm{C}$ (Rita, 2014).

Peralatan medis yang telah digunakan untuk pasien harus dimusnahkan lantaran sangat berbahaya bagi kesehatan masyarakat. Limbah medis seperti jarum suntik harus dimusnahkan, pemusnahannya tidak sembarangan, tapi menggunakan alat Incenerator. Bahkan hasil pemusnahannya tidak dibuang sembarangan. Ketentuan ini juga berlaku di lingkungan puskesmas yang sudah seharusnya memiliki alat tersebut, karena di lingkungan puskesmas juga memiliki limbah berbahaya. kalau tidak ada alat untuk pengolahan limbah, maka puskesmas tersebut harus membawa limbah berbahaya ini ke rumah sakit jika sudah tersedia, termasuk jarum suntik dan obat-obatan ke rumah sakit untuk dimusnahkan atau dihancurkan.

Berdasarkan data dinas kesehatan Kabupaten Sumenep bahwa puskesmas bluto merupakan puskesmas utama dengan akreditasi A sehingga mengharuskan pada setiap kegiatan tidak menimbulkan masalah salah satunya adalah kegiatan pelayanan kesehatan yang menghasilkan limbah padat medis maupun limbah cair, terdapat 17 Pos kesehatan Desa yang ada di bawah tanggung jawab Puskesmas Bluto. Berdasarkan data Limbah medis padat yang di hasilkan dari kegiatan pelayanan poskesdes berkisar antara 0,5 kg perbulan sampai dengan $2 \mathrm{~kg}$ per bulan setiap poskesdes namun pada puskesmas Kecamatan Bluto tidak memiliki incenerator untuk melakukan pembakaran pada sampah medis padat yang di hasilkan oleh kegiatan dari 17 Pos Kesehatan Desa di Kecamatan Bluto. Berdasarkan latar belakang tersebut, maka penelitian ini bertujuan untuk mengetahui gambaran pengelolaan sampah medis padat pada pos kesehatan desa di Kecamatan Bluto.

\section{METODE}

Penelitan ini menggunakan metode deskriptif. Menurut Arikunto dinyatakan bahwa penelitian deskriptif adalah penelitian yang dimaksudkan untuk menyelidiki keadaan, kondisi atau hal lain-lain yang sudah disebutkan yang hasilnya dipaparkan dalam bentuk laporan penelitian. Obyek ini diantaranya petugas kesehatan lingkungan di Puskesmas Bluto dan 2 staff petugas kesehatan lingkungan di Puskesmas Bluto. Instrumen penelitian menggunakan lembar wawancara, dan lembar observasi menggambarkan pengelolaan limbah medis padat pada 17 poskesdes di Kecamatan Bluto.

\section{HASIL DAN PEMBAHASAN \\ Penampungan dan Pemilihan Limbah Medis Padat}

Berdasarkan hasil observasi dan wawancara pada petugas limbah medis padat di puskesmas bluto di dapatkan hasil bahwa dari 17 poskesdes di Kecamatan Bluto yang menggunakan wadah limbah medis dan limbah non medis terpisah sebanyak 17 poskesdes dengan presentase $100 \%$ dan poskesdes yang tidak menggunakan wadah limbah medis dan limbah non medis terpisah sebanyak 0 poskesdes dengan presentase $0 \%$, dan poskesdes yang melakukan penampungan pada wadah penampung limbah medis padat kuat, tahan karat, kedap air, memiliki tutup yang rapat, tahan terhadap benda tajam dan runcing sebanyak 17 poskesdes dengan presentase 100\% dan poskesdes yang tidak 
melakukan penampungan pada wadah penampung limbah medis padat kuat, tahan karat, kedap air, memiliki tutup yang rapat, tahan terhadap benda tajam dan runcing sebanyak 0 poskesdes dengan presentase $0 \%$. Poskesdes yang melakukan penampungan pada wadah penampungan limbah medis dilapisi kantong plastik berwarna kuning sesuai pedoman sebanyak 15 poskesdes dengan presentase $88 \%$, dan poskesdes yang melakukan penampugan dan pengumpulan Limbah benda tajam dalam satu wadah yang anti bocor dan anti tusuk dan tidak mudah untuk dibuka sebanyak 17 poskesdes dengan presentase $100 \%$.

Tabel 1. Penampungan dan Pemilihan Limbah Medis Padat pada Poskesdes di Kecamatan Bluto

\begin{tabular}{lcccc}
\hline \multicolumn{1}{c}{ Penilaian } & Ya & $\%$ & Tidak & $\%$ \\
\hline $\begin{array}{l}\text { Wadah limbah medis dan limbah non } \\
\text { medis terpisah }\end{array}$ & 100 & 0 & 0 \\
$\begin{array}{l}\text { Wadah penampung limbah medis } \\
\text { padat kuat, tahan karat, kedap air, }\end{array}$ & 17 & 100 & 0 & 0 \\
memiliki tutup yang rapat, tahan & & & & \\
terhadap benda tajam dan runcing & & & \\
$\begin{array}{l}\text { Wadah penampung limbah medis } \\
\text { dilapisi kantong plastik berwarna }\end{array}$ & & & & 11 \\
kuning sesuai pedoman \\
$\begin{array}{l}\text { Limbah benda tajam harus } \\
\text { dikumpulkan dalam satu wadah }\end{array}$
\end{tabular}

Penampungan dan pemilahan adalah tempat atau wadah pengumpulan sementara limbah medis padat untuk kemudian dilakukan pemilahan pada limbah padat medis. Pada 4 sub variabel penilaian, sub variabel wadah penampungan limbah medis dilapisi kantong plastik berwarna kuning sesuai pedoman sebanyak $11 \%$ yang tidak melakukan pewadahan pada plastik kuning sesuai pedoman hal ini berkaitan dengan jumlah kantong plastik yang tidak mencukupi. Kantong plastik kuning merupakan penanda atau pembeda antara limbah medis padat dan limbah non medis lainnya tempat penampungan limbah di setiap ruangan yang menghasilkan limbah medis padat sebanyak 50\% karena Poskesdes - Poskesdes tersebut hanya ada 1 sampai 2 penampungan limbah yang langsung di kumpulkan menjadi 1 namun tetap di lakukan pemilahan antara limbah medis padat dan limbah padat non medis.

\section{Pengumpulan Limbah Medis Padat}

Tabel 2. Pengumpulan Limbah Medis Padat pada Poskesdes di Kecamatan Bluto

\begin{tabular}{lcccc}
\hline Penilaian & Ya & $\%$ & Tidak & $\%$ \\
\hline $\begin{array}{l}\text { Tempat pengumpulan dan } \\
\text { penampungan sementara segera }\end{array}$ & 14 & 82 & 3 & 18 \\
disenfeksi setelah di kosongkan & & & & \\
$\begin{array}{l}\text { Terdapat tempat penampungan } \\
\text { limbah disetiap ruangan yang } \\
\text { menghasilkan limbah medis }\end{array}$ & & & & 50 \\
padat
\end{tabular}

Berdasarkan hasil observasi dan wawancara pada petugas limbah medis padat di Puskesmas Bluto didapatkan hasil bahwa dari 17 Poskesdes di 
Kecamatan Bluto yang mendisenfeksi tempat pengumpulan dan penampungan sementara sebanyak 14 poskesdes dengan presentase $82 \%$ dan yang tidak mendisenfkesi tempat penampungan dan pengumpulan sebanyak 3 poskesdes dengan presentase $18 \%$. Pada variabel penilaian tempat penampungan disetiap ruang yang menghasilkan limbah medis sebanyak 7 poskesdes dengan presentase $50 \%$ dan yang tidak terdapat tempat penampungan di setiap ruang yang menghasilkan limbah medis sebanyak 7 poskesdes dengan presentase $50 \%$. Pengumpulan limbah medis padat merupakan wadah sementara untuk kemudian disenfeksi pada wadah sebelumnya, sebanyak $18 \%$ yang tidak melakukan disenfeksi hal ini berkaitan dengan jumlah disenfektan yang tidak memadai.

\section{Pengangkutan Limbah Medis Padat}

Tabel 3. Pengangkutan Limbah Medis Padat pada Poskesdes di Kecamatan Bluto

\begin{tabular}{lcccc}
\hline Penilaian & Ya & $\%$ & Tidak & $\%$ \\
\hline $\begin{array}{l}\text { Kantong plastik diangkat setiap } \\
\text { hari atau kurang sehari jika 2/3 }\end{array}$ & 10 & 58 & 7 & 42 \\
bagian telah terisi & & & & \\
\hline
\end{tabular}

Berdasarkan hasil observasi dan wawancara pada petugas limbah medis padat di Puskesmas Bluto didapatkan hasil bahwa dari 17 Poskesdes di Kecamatan Bluto sebanyak 10 Poskesdes dengan presentase 58\% yang melakukan pengangkutan setiap hari atau kurang sehari jika $2 / 3$ bagian telah terisi dan yang tidak melakukan pengangkutan setiap hari atau kurang sehari jika 2/3 bagian terisi sebanyak 7 Poskesdes dengan presentase $42 \%$. Pengangkutan limbah medis padat adalah pengangkutan yang dilakukan oleh petugas Poskesdes dan kemudian dikumpulkan pada petugas Puskesmas untuk dilakukan tindakan selanjutnya, terdapat $58 \%$ yang melakukan pengangkutan setiap hari atau kurang dari sehari jika limbah medis padat sudah terisi 2/3.

\section{Pemusnahan dan Pembuangan Akhir Limbah Medis}

Tabel 4 : Pemusnahan dan pembuangan Akhir Limbah Medis Padat pada Poskesdes di Kecamatan Bluto

\begin{tabular}{lcccc}
\hline Penilaian & Ya & $\%$ & Tidak & $\%$ \\
\hline $\begin{array}{l}\text { Pemusnahan limbah infeksius, } \\
\text { sitotoksis dan farmasi dengan }\end{array}$ & 17 & 100 & 0 & 0 \\
incenerator (suhu $1000^{\circ} \mathrm{C}$ ) atau & & & & \\
khusus untuk limbah infeksius \\
dapat disterilkan dengan auto \\
clave. yang tidak memiliki
\end{tabular}

Berdasarkan hasil observasi dan wawancara pada petugas limbah medis padat di Puskesmas Bluto didapatkan hasil bahwa dari 17 Poskesdes di Kecamatan Bluto yang melakukan pemusnahan limbah infeksius, sitotoksis dan farmasi dengan incenerator (suhu $1000^{\circ} \mathrm{C}$ ) atau khusus untuk limbah infeksius dapat disterilkan dengan auto clave sebanyak 17 Poskesdes dengan presentase $100 \%$ dan yang tidak melakukan pemusnahan limbah infeksius, sitotoksis dan 
farmasi dengan incenerator (suhu $1000^{\circ} \mathrm{C}$ ) atau khusus untuk limbah infeksius dapat disterilkan dengan auto clave sebanyak 0 Poskesdes dengan presentase 0\%, bagi Poskesdes yang tidak memiliki incenerator melakukan kerjasama dengan MoU dengan pihak yang memiliki incenerator sebanyak 17 dengan presentase $100 \%$ dan poskesdes yang tidak memiliki incenerator dan tidak melakukan kerjasama dengan MoU dengan pihak yang memiliki incenerator sebanyak 0 Poskesdes sebanyak 0\%. Pemusnahan limbah medis padat Poskesdes di lakukan $\geq 24$ jam sebanyak 17 Poskesdes dengan presentase $100 \%$ dan Poskesdes yang tidak melakukan pemusnahan limbah $\geq 24$ jam sebanyak 0 Poskesdes dengan presentase $0 \%$.

Pemusnahan dan pembuangan akhir merupakan kegiatan akhir yang dilakukan untuk menghindari terjadinya infeksi akibat limbah medis padat pada masyarakat atau pada petugas, dari 3 sub variabel pemusnahan dan pembuangan akhir semua aspek memenuhi syarat karena pemusnahan dan akhir dilakukan oleh pihak ke tiga dengan membayar setiap $33000 / \mathrm{kg}$, hal ini berkaitan dengan peraturan pemerintah yang menyatakakan bahwa pengelolaan limbah medis padat harus dilakukan oleh pihak ketiga dan tidak adanya incenerator yang dimiliki oleh puskesmas. Hasil penelitian inis sesuai dengan hasil penelitian Maulana dkk (2015) yang mendapatkan bahwa limbah padat dengan menggunakan incinerator, pembuangan hasil pembakaran di Rumah Sakit Jogja yang telah menjadi abu dibiarkan tetap berada dalam incinerator, setelah abu terkumpul selanjutnya dibuang di penampungan lumpur limbah rumah sakit.

Pemilahan, Pewadahan, pemanfataan kembali dan daur ulang dilakukan pemilahan jenis lirnbah medis padat mulai dari sumber yang terdiri dari limbah infeksius, limbah patologi, limbah benda tajam, limbah farmasi, limbah sitotoksis, iimbah kimiawi, limbah radioaktii limbah kontainer bertekanan dan limbah dengan kandungan logam berat yang tinggi. Tempat pewadahan limbah medis padat terbuat dari bahan yang kuat, cukup ringan, tahan karat, kedap air, dan mempunyai permukaan yang halus pada bagian dalamnya, misalnya $f i$ berglass, pada setiap sumber penghasil limbah medis harus tersedia tempat pewadahan yang terpisah dengan limbah padat non-medis. Kantong plastik diangkat setiap hari atau kurang sehari apabila 2/3 bagian telah terisi limbah, untuk benda-benda tajam hendaknya ditampung pada tempat khusus (safefy box) seperti botol atau karton yang aman. Tempat pewadahan limbah medis padat infeksius dan sitotoksik yang tidak langsung kontak dengan limbah segera dibersihkan dengan larutan disinfektan apabila akan dipergunalan kembali, sedangkan untuk kantong plastik yang telah dipakai dan kontak langsung dengan limbah tersebut tidak boleh digunakan lagi, bahan atau padatan yang dapat dimanfaatkan kembali setelah melalui sterilisasi meliputi pisau bedah (scapel), jarum hipodermik, syringes, botol gelas dan kontainer. Alat-alat lain yang dapat dimanfaatkan kembali setelah melalui sterilisasi adalah radionukleida yang telah diatur (Depkes RI, 2013).

\section{PENUTUP}

Pengelolaan limbah medis padat pada 17 poskesdes di Kecamatan Bluto dari 4 aspek mulai dari penampungan dan pemilahan, pengumpulan, pengangkutan serta pemusnahan dan pembuangan akhir secara keseluruhann sudah baik hal ini berkaitan dengan koordinasi antara petugas poskesdes dan petugas puskesmas untuk melakukan pengelolaan limbah padat medis yang baik dengan melakukan MoU dengan pihak ketiga sebagai pihak yang akan melakukan kegiatan akhir pada limbah media padat. 


\section{DAFTAR PUSTAKA}

Agustina A. 2014. Kajian Pengelolaan Limbah Di Rumah Sakit Umum Provinsi Nusa Tenggara Barat (NTB). Universitas Udayana. Vol 2 No 1.

Birpınar ME. Bilgili MS. Erdogan T. 2009. Medical waste management in Turkey: A case study of Istanbul. Waste Management. vol 29. 445-448.

Depkes RI. 2013. Pedoman pelaksanaan pengelolaan limbah cair dan padat pada rumah sakit. Depkes RI. Jakarta.

Maulana M. Kusnanto H. Suwarni A. 2015. Manajemen pengolahan limbah pada rumah sakit Jogja. Kesmas. 9(1); $69-76$.

Rita S. 2014 Pengelolaan Limbah Medis Padat Pada Proses Pembakaran Mengunakan Incenerator Manual Di Rsud Inche Abdoel Moeis Samarinda Kalimantan Timur: Politeknik Pertanian Negeri Samarinda.

WHO. 2005. Pengelolaan Limbah Aman Layanan Kesehatan. Cetakan Pertama. EGC. Jakarta. 